\title{
Articles
}

\section{Intentional use of te reo Māori in New Zealand newspapers in 2007}

\section{ABSTRACI}

This study aimed to measure the intentional use of words in te reo Māori in a representative sample of newspaper news items about Māori issues. While te reo Māori was made an official language in 1987, it remains endangered and New Zealand remains one of the most monolingual countries in the world. The news items analysed were about Māori issues, and thus more likely to include Māori words. Only words with an alternative in English were counted, and the origin of articles was analysed. Forty-five percent of items included no Māori words with an alternative in English, and the average across the sample was 2.4. More than half the Māori words counted described social culture. Use of te reo varied widely among newspapers. No regular Māori language promotion items appeared in the sample, and it provides little evidence of support for New Zealand's endangered indigenous official language.

Keywords: iwi radio, language, newspapers, te reo Māori, Treaty of Waitangi

JENNY RANKINE (Pākehā), ANGELA MOEWAKA BARNES (Ngāpuhi Nui Tonu), BELINDA BORELL (Ngāti Ranginui, Ngai Te Rangi, Whakatohea), HECTOR KAIWAI (Ngāti Porou/Ngāti Maniapoto/Tuhoe), RAYMOND NAIRN (Pākehā), TIMOTHY McCREANOR (Pākehā) and AMANDA GREGORY (Pākehā) Kupu Taea Project, Massey University

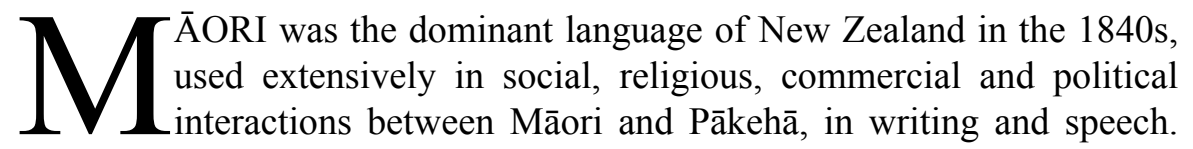


This changed in the 1850s, when Pākehā began to outnumber Māori (Te Taura Whiri i te Reo Māori, 2008) and assert their political aspirations.

Colonisation gradually and deliberately restricted the use of te reo Māori to Māori communities (Richmond, 1867), through changes to the education system and entrenchment of Pākehā procedures in domains such as justice, health and commerce (Archives NZ, 2003). Māori concern about the survival of the language built from the 1930s, and this sparked a petition organised by Ngā Tamatoa and presented to Parliament in 1972 (Te Puni Kōkiri, 2008).

A survey of Māori language use undertaken in the 1970s by the New Zealand Council for Educational Research (Benton, 1991) provided clear evidence that the language was in rapid decline and would soon disappear unless drastic measures were urgently undertaken. In response, Māori established the kōhanga reo movement, kura kaupapa Māori, tribal wananga reo, other active language teaching, a Waitangi Tribunal claim, iwi radio stations and eventually Māori Television. These often used voluntary labour and initially received little official funding.

While this history is often described as language loss followed by revitalisation initiatives, Bernard Spolsky (2003) argues that it is the result of a long process of challenge and negotiation between Māori and settlers. Apirana Ngata envisaged te reo among the taonga to which he advised young people to hold true in his famous song E tipu e Rea. The 1986 Waitangi Tribunal claim sought to have te reo Māori recognised as one of the taonga guaranteed government protection under the Treaty of Waitangi (Waitangi Tribunal, 1989).

The Tribunal supported the claim and its recommendations led to a commitment from the government to support Māori language revitalisation initiatives. The Māori Language Act 1987 recognised te reo Māori as a taonga guaranteed to Māori, established Māori as an official language of New Zealand and set up Te Taura Whiri i te Reo Māori (the Māori Language Commission) (Te Taura Whiri i te Reo Māori, 2008).

However, the Māori language is still endangered, with only 23 percent of Māori and a very small number of non-Māori able to hold a conversation in te reo (Te Puni Kōkiri, 2008). About 80 percent of fluent Māori speakers are aged over 35 .

Almost a third of fluent speakers in the North Island live in Auckland. Other fluent speakers are concentrated in the urban centres and rural communities of Northland, Waikato, the Bay of Plenty and the East Cape (Te Taura 
Whiri i te Reo Māori, 2009). The decline in fluent Māori speakers has meant that New Zealand is one of the most monolingual countries in the world, with English the only language for 90 percent of the population (Bellett, 1995).

One goal of the government's Māori language strategy is that 'The Māori language will be valued by all New Zealanders and there will be a common awareness of the need to protect the language' (Te Puni Kōkiri \& Te Taura Whiri i Te Reo Māori, 2003). Newspapers are major language users, whose handling of te reo Māori could play a major role in reaching that goal. However, established measures of their use of te reo indicate their very low level of support for the language.

\section{Use of te reo in English}

The presence of words originating in te reo Māori is the most distinctive feature of New Zealand English. Early adoption of Māori words into English was driven by the needs of Pākehā to understand terms in the dominant language and to name their environment, while the second and ongoing influx of Māori words into English in the late 1990s was driven by Māori (Bartlett, 2002; Kennedy, 2001).

Macalister (2006) surveyed a corpus from newspapers, Hansard and the School Journal at 30 year intervals from 1850 to 2000 . He found that the frequency of words of Māori origin steadily increased from just over three words per thousand in 1850 to almost nine per thousand in 2000 (Macalister, 2006). The study categorised Māori terms as proper nouns, flora and fauna, material culture (nouns for visible and tangible objects) and social culture (terms for intangible concepts, actions and relationships). Proper nouns made up more than 90 percent of all the Māori words in each year surveyed. However, analysis of the other categories showed a striking growth in frequency of Māori words for social culture between 1970 and 2000. The last year sampled also had the highest totals of any year for the three common noun categories.

Analyses based on observation (eg. Deverson, 1991) identified a different balance of semantic categories of te reo Māori in New Zealand English to computer-based corpus studies. Two analyses of contemporary collections of written and spoken New Zealand English found that 60 percent of terms were place, personal names and other proper nouns; words about tikanga Māori were the second largest group and words about flora and fauna the third largest (Kennedy \& Yamazaki, 1999; Macalister, 1999). 
The two studies used different source documents but both found that words of Māori origin made up roughly six words per thousand in the late 1990s.

Kennedy and Yamazaki analysed the Wellington Corpus of Written New Zealand English (WWC) and the Wellington Corpus of Spoken New Zealand English (WSC). The WWC includes 44 press reports, 27 editorials and 17 reviews, making up 9, 6 and 3 percent of the collection respectively.

Speakers in the WSC who identified as Māori used more than 17 Māori words per 1000 words when speaking English. Pākehā speakers used about two per 1000 and other people used less than one per 1000 words. Bellett (1995) also found that Māori survey participants knew and used significantly more Māori words than non-Māori; people who described themselves as Kiwi knew the lowest number of Māori words.

Different lists of the most common Māori words in New Zealand English have been compiled using different methodologies and source material (Table 1). Trudgill and Hannah (1994) listed words found in New Zealand books and newspapers without translation. Bellett (1995) listed the 21 best known Māori words from a subjective list of 100 as ranked by his sample of South Island children and women. Kennedy's list includes the most commonly used words from the WWC that are not personal or place names (apart from Aotearoa), in their rank order (2001).

One small survey of Māori and Pākehā New Zealanders found that 14 Māori terms for occupations were known by most Māori and some Pākehā speakers (Westbrook, 2006). They included kaiawhina, tumuaki, kaumātua, kaiako, kaiwhakahaere and ringawera. The terms were used in job advertisements in five newspapers and a jobs website. Survey participants agreed that Māori words made New Zealand English unique and were a source of cultural identity for all New Zealanders. However, opinions differed on whether words in te reo Māori in job ads provided clarity, were attractive or effective.

Words about social culture have dominated lists of Māori terms that other commentators said should be widely known (King, 1985; Ministry of Culture \& Heritage, 2008; Keegan, 2009). However, a survey of 674 Wellington senior secondary students in 2002 found that the largest proportion of well-known words described flora and fauna (Macalister, 2006).

Female students showed greater familiarity with Māori words than male students, but Māori word knowledge was similar across the socio-economic spectrum. The study concluded that non-Māori speakers of New Zealand 
Table 1: Most common Māori words in New Zealand English

\begin{tabular}{|c|c|c|}
\hline Trugill \& Hannah & Belett & Kennedy \\
\hline Aroha & Aotearoa & Māori \\
\hline Haka & Haere mai & $\mathrm{Te}$ \\
\hline Hui & Haka & Pākehā \\
\hline Iwi & Hāngī & Kiwi \\
\hline Kaumātua & HUhu & Aotearoa \\
\hline Kaupapa & Kai & Marae \\
\hline Mana & Kauri & Kākāpō \\
\hline Marae & Kia ora & Tāngata \\
\hline $\mathrm{Pā}$ & Kiwi & Tiriti \\
\hline Paepae & Kūmara & $\mathrm{Pā}$ \\
\hline Pākehā & Mānuka & Whenua \\
\hline Pōwhiri & Māori & Aroha \\
\hline Rangatira & Marae & $E$ \\
\hline Rangatiratanga & Moa & Haka \\
\hline Rūnanga & Pākehā & Kai \\
\hline Tāngata & Pāua & Pōhutukawa \\
\hline Taniwha & Poi & Manuhiri \\
\hline Tapu & Puka & Tohunga \\
\hline Taua & Pūkeko & Kauri \\
\hline Tauiwi & Tapu & Moko \\
\hline Umu & Tūī & Ngā \\
\hline Waka & & Rua \\
\hline Whare & & Takahē \\
\hline Whakapapa & & Mānuka \\
\hline \multirow[t]{3}{*}{ Whenua } & & Tihei \\
\hline & & Hui \\
\hline & & Kēhua \\
\hline
\end{tabular}

English know more than the previously estimated 40 to 50 Māori words (Deverson, 1984), and that further expansion is likely, particularly from words describing social culture.

The same survey was repeated in 2007 in Wellington with 724 Year 13 students and found a 4 percent increase in the proportion of Māori social culture words that were reasonably well-known. Girls still showed more 
familiarity with te reo, despite boys having been more likely to study te reo Māori (Macalister, 2008).

Te Taura Whiri i te Reo Māori advocates the use of macrons on Māori words in English, because this mark of vowel length enables English speakers to stress the appropriate syllables, and thus improve their pronunciation of Māori. Bauer (1995) summarised overseas research, which shows that the use of forms from dominant languages ultimately leads to the replacement of features of threatened languages with those of the dominant one. 'Māori cannot afford to lose any more ground' (p. 21).

Leek (1989) found that Pākehā New Zealanders were generally reasonably well disposed towards the expansion of Māori into new domains, provided they were not expected to learn the language.

\section{Use of te reo Māori in English language news media}

Davies and Maclagan (2006) describe earlier newspaper style conventions as reflecting purist attitudes to the English language that decreed that te reo Māori would be subject to the rules of English grammar. Now its own rules are applied, reflecting the stronger social and political status of te reo Māori.

In 1989, the New Zealand Journalists' Union agreed that members would no longer make Māori words plural by adding an 's' (Deverson, 1991), and in 1995 Bellett described this convention as widely accepted among many Pākehā speakers.

Davies and Maclagan surveyed the use of 13 Māori words in the news sections of four Fairfax newspapers, the Waikato Times, the Dominion Post, the Press and the Southland Times, from 1997 to 2004. The words were hui, hikoi, iwi, kaumātua, kaupapa, kaitiaki, marae, nohoanga, taiapure, tangata whenua, whakapapa, whānau and the English plural Māoris. Articles containing these words were used more often over the survey period.

Excluding Māoris, the most common words were iwi, marae, hui, whānau, kaumātua and tangata whenua. Of these, only kaumātua was regularly translated, and there was a trend away from translating all the search words. The least common words were nohoanga, taiapure and kaitiaki. The words were almost all found in articles about Māori issues, although hui and hikoi were occasionally used in non-Māori contexts.

The words whose frequency remained steady or increased all described social culture. The meaning of marae changed during the survey period to 
include a community of interest as well as a space or building. The word Māoris was extremely rare in the Waikato Times and the Southland Times. In the Christchurch Press and Dominion Post, it was very common until 2001, when the papers' style changed to allow -s plural suffixes for Māori words only in direct quotes. Since that time, newspapers have allowed some rules governing use of te reo Māori to apply in English, again reflecting the stronger position of te reo Māori.

In 2000, the New Zealand Herald, the Dominion and the Wanganui Chronicle together allowed 28 words in te reo Māori to be published untranslated, a 'relatively small number' (Macalister, 2006). The Herald did not translate 18, the Dominion 16 and the Wanganui Chronicle six. The only word all three papers agreed did not need translating was iwi.

Kennedy (2001) described newspapers' 'conservative interpretation of what [Māori words are] familiar', giving the example of kōhanga reo, which newspapers continued to translate as language nurseries, 'even though this pre-school movement is well-established' (p. 62).

Macalister (2001) tracked use of the word Māori in a corpus drawn only from news and opinion items in four newspapers. He found that the Wanganui Chronicle included the highest frequency of the word Māori ( 0.13 percent), followed by the Dominion Post (0.08 percent), the New Zealand Herald ( 0.05 percent) and the Otago Daily Times (0.04 percent). The word Māori occurred most frequently in items about politics, which were three times more common in the Dominion Post than in the other two metropolitan dailies.

In another study in 2006, Macalister found that newspapers used almost eight Māori words per thousand in 2000. While place and personal names made up more than 95 percent of the total, words for social culture made up 2.5 percent, followed by flora and fauna terms ( 1.4 percent) and words about material culture ( 0.4 percent).

De Bres (2006) compared television news from 1984 and 2004 and found a very low frequency of Māori words in both years. Most Māori terms were proper nouns, almost all were used in items about Māori issues, and more were used by Māori than by Pākehā speakers. Moewaka Barnes et al (2005) analysed intentional use of te reo Māori in 20 television news items about Māori issues in a 14-day representative sample from 2004. This excluded almost all proper nouns. They found that 14 items contained no Māori words or phrases with English alternatives. Of the six items that did, seven Māori words were used 16 times. 
Broadcast news, weather and commentary from the early 1990s made up 4 percent of the WSC and shows results consistent with this picture. This part of the WSC had a much higher proportion of Māori words (13 percent), but almost all were personal and place names (Kennedy, 2001).

\section{Methodology}

We collected a newspaper sample using two constructed weeks drawn from February and March 2007. A constructed week is made by choosing the individual weekdays randomly from the specified period, at least six weeks prior to collection. This method reproduces the systematic variations in the number of news items across weekdays and is less vulnerable to week by week fluctuations in story numbers (Lacy et al, 2001).

We contracted Chong Newztel Ltd for copies of all editorial newspaper items that included any of the following words or phrases:

- Treaty of Waitangi/te Tiriti o Waitangi

- Māori-Pākehā relations

- Disparities between Māori and non-Māori/mainstream

- Sovereignty

- Land Rights

- Foreshore and seabed

- Waitangi Tribunal

- Māori development

- Constitutional change

- Iwi/hapū/whānau

- Māori health.

\section{Defining a Māori news sample}

Journalists describe items about the Treaty and Māori/Pākehā relations as Māori news. While we believe these items are equally relevant to non-Māori New Zealanders, for this research we also called them Māori items. Items were defined as Māori news if they focused on:

- Treaty of Waitangi issues or Waitangi Day

- Māori control of resources

- Legislation and protest about this

- Māori arts, cultural, religious and sporting activities

- Māori health and education

- Iwi and other Māori organisational and business activity 
- Māori involvement in political processes

- The history of Māori occupation

- Historical or current relations between Māori and Pākehā

- The socio-economic status of Māori

- Individual Māori with one or more of the above criteria.

The keyword search yielded a total of 1048 items. Māori issues were peripheral in 308, leaving 740 Māori news items.

\section{Origin of newspaper items}

More than three-fifths of Māori news items were produced by the newspaper in which they were published (see Table 2). New Zealand Press Association (NZPA) items made up more than a quarter and nine percent were from other papers under the same ownership.

The origin of items was initially coded according to acknowledgements in the item. However, some local or provincial papers published items without any acknowledgement that were identical to those published in other papers where they were identified as coming from NZPA or another outside source. These items were re-coded as NZPA and suggest that other items originating from NZPA may not have been identified.

\section{Analysis}

Our analysis aimed to identify newspapers' intentional use of Māori terms. For this reason we only counted terms where there was an alternative in English. This meant that we did not count most Māori proper names or most flora and fauna terms. For example, paua was not counted, but whānau (family) was. Rotorua was not counted but Maungakiekie (One Tree Hill) was. Iwi names were counted if they were provided as part of an iwi affiliation not connected to the topic of the item.

Table 2: Origin of newspaper Māori items

\begin{tabular}{|l|c|c|}
\hline \multicolumn{1}{|c|}{ Origin } & Number & Percentage \\
\hline Paper's own staff & 462 & 62.4 \\
\hline NZPA & 211 & 28.5 \\
\hline Other (eg) Fairfax) & 67 & 9.1 \\
\hline Totals & 740 & 100 \\
\hline
\end{tabular}


The same word, such as kōrerō (speech), could be recorded as an individual word or as part of a phrase such as kōrerō tuku iho (stories handed down). Each counted as one unit of te reo Māori.

One team member searched newspaper items for every Māori word or phrase for which there is an alternative in English (Table 3). Newspaper items were scanned and imported into Microsoft Word and then into QSR's qualitative research programme N6. The programme was used to search for each identified word and to count occurrences. This data was entered into an Excel spreadsheet. Further, words were coded according to whether they appeared in headlines or subheadings, first paragraph, or in the body of the item, and whether they were translated.

Table 3: Te reo Māori terms
\begin{tabular}{|l|c|}
\hline Number of different items & 199 \\
\hline Translated & 126 \\
\hline Total terms in Te reo Maori & 1778 \\
\hline Proportion of total words & $0.09 \%$ \\
\hline
\end{tabular}

\section{Findings}

Our sample was selected because it contained search keywords about Māori or in te reo Māori; the corpus was therefore more likely to contain words in te reo Māori than news articles in general. Just over half the sample (55 percent) included at least one word of te reo Māori for which there was an English alternative. A quarter of these items used only one Māori term. The 740 items used an average of 2.4 terms in te reo Māori.

Some words commonly used in spoken New Zealand English (see Table 1), such as Aotearoa, kai, pōwhiri, wairua and whānau were each translated at least once. The majority of te reo Māori words described social culture (Table 4).

Table 4: 2007 Māori term semantic categories
\begin{tabular}{|c|c|c|c|c|}
\hline Social culture & Material culture & Proper nouns & Flora and fauna & Total \\
\hline 121 & 46 & 24 & 9 & 200 \\
\hline $61 \%$ & $23 \%$ & $12 \%$ & $4 \%$ & $100 \%$ \\
\hline
\end{tabular}


Proper nouns included iwi affiliations, place and organisation names. Flora and fauna included six plants and three animals. The eight most commonly used non-proper noun words with an alternative in English were almost all about social culture, and between them made up half the total number of te reo Māori words in the sample (Table 5).

\section{Table 5: Eight most common te reo Mãori terms}

\begin{tabular}{|c|c|c|c|c|c|c|c|c|}
\hline iwi & marae & Pakeha & $\begin{array}{c}\text { kauma- } \\
\text { tua }\end{array}$ & haka & hapu & whanau & $\begin{array}{c}\text { tino } \\
\text { rangati- } \\
\text { ratanga }\end{array}$ & Totals \\
\hline 360 & 108 & 89 & 86 & 70 & 62 & 59 & 58 & 892 \\
\hline $20.2 \%$ & $6.1 \%$ & $5 \%$ & $4.8 \%$ & $3.9 \%$ & $3.5 \%$ & $3.3 \%$ & $3.3 \%$ & $50.1 \%$ \\
\hline
\end{tabular}

Six items included more than 20 words in te reo Māori. A Dominion Post feature about the international adoption of the haka included 42. A news item in the Bay of Plenty Times about the transfer of ownership of Mauao (Mt Maunganui) into iwi hands included 27. Two items included 26 Māori terms - a feature in the Bay Weekend about Ngāti Awa head Jeremy Gardiner and a New Zealand Herald news item about a kōhanga reo. A news item in the Wanganui Chronicle about the signing over of the city's courthouse to iwi as part of a Treaty settlement included 24. A Turangi Chronicle item about tertiary education supplied by Korohe Marae included 22.

Eight Māori sentences, two untranslated, were used in the whole sample, all by Māori sources. Four sentences came from a haka about Te Arawa soldier Haane Manahi, quoted in one Daily Post item. The Daily Post also published an untranslated sentence in te reo Māori by a Māori columnist. Other sentences in te reo Māori were used by a Māori conference presenter quoted in the Wanganui Chronicle, Dun Mihaka quoted in the Northern Advocate and a co-ordinator of a te reo Māori course quoted in the Turangi Chronicle.

The Treaty was referred to by its Māori name 11 times, ten by Māori sources. The phrase tino rangatiratanga (Māori self-determination) was used 58 times, almost all by Māori sources in items about the flag, ownership of fresh water and Waitangi.

Eight items gave the iwi affiliations of people mentioned. Ten place names for which there were English alternatives were mentioned 63 times in 33 items. 


\begin{tabular}{|c|c|c|c|c|c|c|c|c|c|c|c|c|c|c|c|c|c|c|c|c|c|c|}
\hline $\begin{array}{l}\frac{\vec{O}}{\Phi} \\
\frac{\mathrm{N}}{\omega}\end{array}$ & 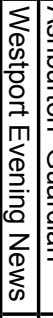 & 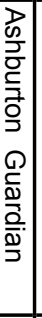 & 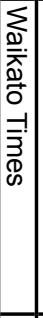 & 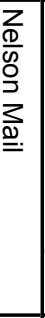 & 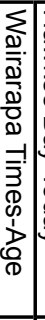 & 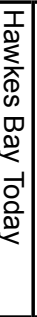 & 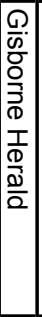 & 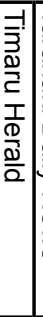 & 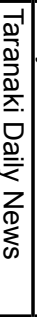 & 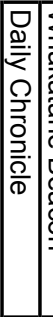 & 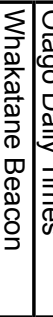 & 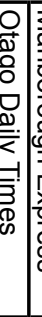 & 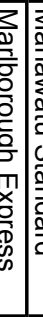 & 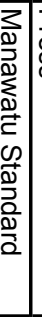 & 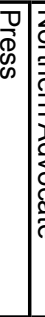 & 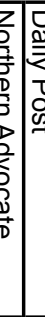 & 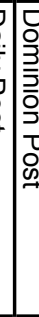 & 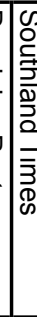 & 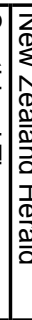 & 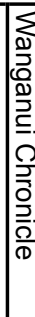 & 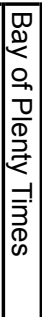 & 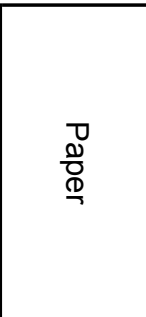 \\
\hline & $\infty$ & Nol & $\omega$ & $\hat{N}$ & $\mid$ & $\begin{array}{l}\omega \\
\infty\end{array}$ & ब & $\vec{\omega}$ & $\stackrel{\vec{A}}{ }$ & $\vec{\bullet}$ & 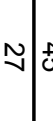 & $\overrightarrow{\mathrm{v}}$ & $\omega$ & $\underline{\omega}$ & $\overrightarrow{\vec{v}}$ & $\overrightarrow{\mathrm{U}}$ & $\overrightarrow{\vec{b}}$ & $\frac{1}{c}$ & \begin{tabular}{|l}
$\bar{C}$ \\
$\bar{C}$
\end{tabular} & $\stackrel{c}{\hookrightarrow}$ & G & 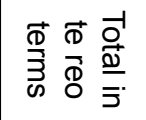 \\
\hline$\stackrel{+}{0}$ & $\vec{N}$ & $\vec{\omega}$ & ه & $\mathbb{v}$ & O & $\underline{\omega}$ & $\mathrm{N}$ & $\underline{\omega}$ & $\underline{\omega}$ & 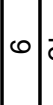 & $\vec{\omega} \mid \vec{c}$ & Nol & $\overrightarrow{\mathrm{v}}$ & $\vec{\sigma}$ & $\vec{N}$ & $\vec{\Delta} \mid \stackrel{f}{N}$ & $\vec{c}$ & $\vec{v}$ & $\frac{f}{N}$ & $N$ & $\overrightarrow{0}$ & $\begin{array}{l}\overrightarrow{\bar{D}} \\
\text { 心 } \\
\text { क }\end{array}$ \\
\hline $\begin{array}{l}\omega \\
\text { N }\end{array}$ & $\Delta$ & $v$ & $\vec{A}$ & 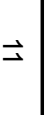 & $\Delta$ & $\vec{\nabla}$ & $\vec{A}$ & 0 & $\overrightarrow{0}$ & ब & $\overrightarrow{0}=$ & $\vec{a}$ & $v$ & $\overrightarrow{0}$ & $\mathcal{G}$ & $\vec{\longrightarrow} \mid \vec{c}$ & D & $\vec{c}$ & 5 & $\vec{c}$ & $\vec{a}$ & 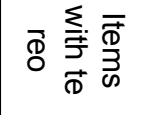 \\
\hline & $\begin{array}{ll}\circ \\
\text { (’) }\end{array}$ & 이 & $\overrightarrow{\text { cr }}$ & $\overrightarrow{\dot{c}}$ & $\vec{\sigma}$ & $\vec{\sigma}$ & $\vec{v}$ & $\overrightarrow{0}$ & $\overrightarrow{0}$ & $N$ & $\sim \mid \hat{i}$ & $\stackrel{N}{N} \mid !$ & $\begin{array}{c}N \\
\omega\end{array}$ & $\begin{array}{l}\sim \\
\omega \\
\omega\end{array}$ & $\stackrel{N}{v}) !$ & $\checkmark)$ & ० & $\mid \begin{array}{c}a \\
\dot{\omega}\end{array}$ & 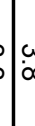 & $A$ & $G$ & 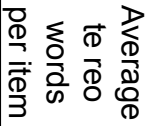 \\
\hline & $N$ & or & $\vec{A}$ & a & 0 & 0 & $|\vec{\sigma}|$ & $\infty$ & $\infty$ & $|r|$ & $\vec{\omega} \mid u$ & $G$ & $N C$ & G & ָै & ق & 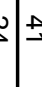 & 7 & $\mid \begin{array}{l}a \\
c\end{array}$ & $\exists$ & 0 & 心 \\
\hline & $1 \rightarrow 0$ & の) & $\omega$ & $\Delta$ & $\vec{v}$ & $N$ & $\left|\begin{array}{l}\omega \\
\oplus\end{array}\right|$ & $\Delta$ & $\vec{A}$ & $\vec{v}$ & $\checkmark$ & $\stackrel{N}{\perp}$ & $\vec{\sim}$ & $\vec{\infty}$ & $\stackrel{\infty}{\sim}$ & 芶 & $\vec{v} \overrightarrow{\vec{\omega}}$ & $a$ & $\frac{7}{\alpha}$ & 7 & $\stackrel{\infty}{v}$ & 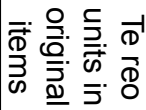 \\
\hline & $\vec{N}$ & $\begin{array}{l}\omega \\
\end{array}$ & $\forall$ & 6 & जि & త్ర & $\stackrel{N}{A}$ & $\bullet$ & W & 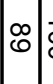 & 이이 & 心) & $\omega$ & $\overrightarrow{0}$ & శు & o & 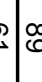 & 8 & $\begin{array}{l}c \\
c \\
0 \\
0\end{array}$ & $\begin{array}{l}\infty \\
\stackrel{c}{c}\end{array}$ & $\begin{array}{l}0 \\
\text { No } \\
0\end{array}$ & 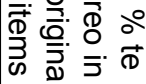 \\
\hline & Ö & $\overrightarrow{\mathrm{N}}$ & $\stackrel{N}{\rightarrow}$ & 이 & $\vec{\sigma}$ & $\stackrel{\sim}{\sim}$ & $\stackrel{\sim}{\sim}$ & 이 & $\vec{v}$ & $\left|\begin{array}{c}\omega \\
\triangleright\end{array}\right|$ & $N$ & $\begin{array}{ll}+ \\
\infty\end{array}$ & $\vec{G}$ & $\begin{array}{c}\omega \\
\sigma\end{array}$ & $\omega$ & $\omega$ & $\omega$ & $\stackrel{+}{\infty}$ & $a$ & 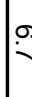 & \begin{tabular}{|l|}
0 \\
0 \\
6
\end{tabular} & 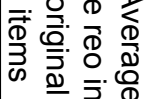 \\
\hline $\overrightarrow{0}$ & 1 & ' & $\triangle$ & $N$ & $\rightarrow$ & $\rightarrow$ & $N$ & $\rightarrow$ & $\rightarrow$ & ' & 1 & $\Delta$ & $N$ & $N$ & $N$ & $v+A$ & $\rightarrow$ & $\omega$ & 1 & $\omega$ & 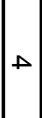 & 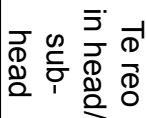 \\
\hline 8 & ' & $\rightarrow$ & $G$ & $\infty$ & $\rightarrow$ & $\omega$ & $N$ & $N$ & $N$ & $\rightarrow$ & $\omega \mid$ & $\Delta$ & $N+$ & $\Delta$ & $V$ & $\begin{array}{l}1 \\
0\end{array}$ & $\pi$ & $1 n$ & $=$ & I & $G$ & 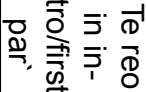 \\
\hline & $\rightarrow$ & $\rightarrow$ & $\omega$ & $\omega$ & $N$ & $\Delta$ & $\triangle$ & $\Delta$ & $\omega$ & N & 10 & $G$ & $\rightarrow$ & ' & $V$ & $\overrightarrow{\mathrm{v}}=$ & $\vec{\Delta} \mid v$ & ( & $0 \bar{c}$ & $\infty$ & $v$ & 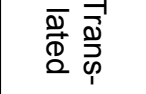 \\
\hline
\end{tabular}


The newspapers with more than nine items in our sample are listed in Table 6. Between 30 to 80 percent of Māori news items in these papers included no Māori words with an alternative in English. Use of te reo Māori in headings was rare-The New Zealand Herald used the most with seven words in 42 items.

Papers that used six or fewer words or phrases in te reo Māori that had English alternatives included the Northland Age, the Greymouth Star, the Sunday Star-Times, the National Business Review, the Oamaru Mail, the Dannevirke Evening News, the West Coast Times and the Southland Express.

The Sunday News and the Herald on Sunday used no te reo Māori terms for which there were English alternatives in their single items.

The Bay of Plenty Times made richest use of te reo Māori in items it originated, using almost four times the average. The Wanganui Chronicle, Marlborough Express, Otago Daily Times and the Southland Times all used two or more times the average number of Māori terms in items by their own staff.

Other papers that used a higher proportion of te reo Māori in their own items compared to those from other sources included The New Zealand Herald, Daily Chronicle, the Manawatu Standard and the Ashburton Guardian. The Whakatane Beacon was the only non-daily paper with more than nine Māori news items in the sample, and the only paper whose Māori items were all generated by its own staff.

The Timaru Herald and Nelson Mail used a lower rate of te reo Māori in their own items.

Spelling and use of te reo Māori was inconsistent; for example, Pākehā was used uncapitalised 15 times and with a capital 78 times. Kapa haka was spelt as one word seven times and as two 20 times.

Inept combinations of Māori and English included 82 instances of "the Te'. Some usages such as 'the Te Hana community' may flow more easily than 'the Te Rūnanga' but all are redundant. Māori nouns such as hapū, iwi, kōhanga, marae and whānau were made possessive or plural by adding an $\mathrm{s}$ in 22 items. There were five 'hakas' and one use of 'wakas'. There were five instances of 'hongis' as a verb (from an NZPA item) and one of 'hongiing', all in captions. We noticed two coinings that have not made their way to $T e$ Aka Māori-English, English-Māori Dictionary; mihini moko - tattoo machine, and Rotovegas for Rotorua. 


\section{Conclusion}

The data confirms very low levels of intentional use of Māori words by one of the premium English language institutions of our society, on average just over two words or phrases of te reo Māori for which there is an English alternative per item. While this may be consistent with the Pākehā commonsense that Māori has low everyday priority (McCreanor, 1989) the practice works to confirm that dismissive judgment.

Nearly half of the Māori news sample did not use a single Māori word for which an English alternative existed and just three words of te reo (iwi, marae and Pākehā) made up nearly one third of those used. The sample included a number of inconsistent and inept uses of te reo Māori terms.

When newspapers use words in te reo Māori such as mana and kaitiakitanga they also convey Māori concepts about control of resources in a way that English words such as authority and guardianship may not. Choosing to use predominantly the English terms for such concepts means that readers are denied access to a Māori world view that currently struggles to be heard and understood.

Newspapers in some areas with a high proportion of Māori residents made better use of te reo than others, including the New Zealand Herald, the Daily Post, the Bay of Plenty Times, the Wanganui Chronicle. Other newspapers in areas with high proportions of Māori used lower than the average number of te reo Māori terms, for example the Gisborne Herald and the Waikato Times. Some newspapers have won awards for promotion of te reo Māori during Māori Language Week, notably the Gisborne Herald and Fairfax NZ Newspapers in Education (Korero Māori, 2008). However, no regular Māori language promotion items appeared in the sample.

Fifty-nine percent of words in te reo were found in items generated by the newspaper's own staff. Fairfax has centralised subediting for its regional daily newspapers, and plans to centralise production in four regional hubs (NZPA, 2009). If these moves result in fewer locally produced items, the proportion of te reo in newspapers could fall below its already low level.

Decisions about use of Māori words in New Zealand English are as much socio-political as linguistic (Bauer, 1995). This representative sample of newspapers showed little evidence of support for New Zealand's endangered indigenous official language. 


\section{Glossary}

Aotearoa - Māori name for the North Island, often used for the whole country. haka - physical demonstration of a challenge accompanied by chanting hapū - sub-tribe

hongi - press noses

hui - meeting, gathering

iwi - a nation of people with a shared identity and genealogy; tribe

kai - food

kaiako - teacher

kaiawhina - assistant

kaitiakitanga - guardianship

kaiwhakahaere - director

kapa haka - cultural performance

karakia - prayer, chant

kaumātua - elder

kōhanga reo - Māori language preschool

kuia - Female elder

kura kaupapa - Māori language school

mahi - work

mana - full authority, sovereignty

marae - Māori meeting house and grounds

Pākehā - New Zealander of European descent

paua - shellfish

pōwhiri - Welcome

ringawere - kitchenhand

rūnanga - ssembly, council

taonga - treasure

Te Arawa - Central North Island iwi

tikanga Māori - Māori custom

tino rangatiratanga - Māori control and self-determination

tumuaki - principal, head

wairua - spirituality

waka - canoe

wananga reo - Māori language seminar/s, course/s, learning

whānau - family that extends beyond the concept of the nuclear or biological family.

wharekura - school

\section{References}

Archives New Zealand. (2003). Akona te Reo: Māori Language in State Education 1840 - 1990: A Resource Kit for Schools. Wellington: Archives New Zealand.

Bartlett, M. (2002). Utu: A bit of give and take? NZ Words 6: 6-7.

Bauer, W. (1995). Languages in contact II: The use of Māori words in English. New Zealand Studies, 5(2): 19-24. 
Bellett, D. (1995). Hakas, hangis and kiwis: Māori lexical influence on New Zealand English. Te Reo, 38: 73-104.

Benton, R. A. (1991). The Mãori language: Dying or reviving? Honolulu: East West Center. (Reprinted by New Zealand Council for Educational Research, 1997).

Davies, C., \& Maclagan, M. (2006). Māori words: Read all about it. Testing the presence of 13 Māori words in four New Zealand newspapers from 1997 to 2004. Te Reo, 49:73-99. de Bres, J. (2006). Māori lexical items in the mainstream television news in New Zealand. New Zealand English Journal, 20: 17-34.

Deverson, T. (1984). Home loans: Māori input into current New Zealand English. English in New Zealand, 33: 4-10.

Deverson, T. (1991). New Zealand English lexis: The Māori dimension. English Today, 26: 18-25.

Kennedy, G., \& Yamazaki, S. (1999). The influence of Māori on the New Zealand English lexicon. In Kirk, J. M. (Ed), Corpora galore: Analyses and techniques in Describing English (pp. 33-44). Amsterdam: Rodopi.

Kennedy, G. (2001). Lexical borrowing from Māori in New Zealand English. In Moore, B. (Ed), Who's centric now? The present state of post-colonial Englishes (pp. 59-81). Melbourne: Oxford University Press.

King, M. (1985). Kawe korero: A guide to reporting Māori activities. Pukekohe: New Zealand Journalists' Training Board.

Korero Māori. (2008). Pānui hōu, Press releases, www.korero.maori.nz/news/press, Retrieved on 30 April 2009, from www.korero.maori.nz/news/press

Lacy, S., Riffe, D., Stoddard, S., Martin, H., \& Chang, K-K. (2001). Item size for newspaper content analysis in multi-year studies. Journalism \& Mass Communication Quarterly, 78: 836-845.

Leek, R. (1989). Attitudes to the Mãori language in New Zealand. Paper presented at the 8th New Zealand Linguistics Society Conference. Auckland.

Macalister, J. (2008). Tracking changes in familiarity with borrowings from te reo Māori. Te Reo, 51: 75-97.

Macalister, J. (2006). Of weka and waiata: Familiarity with borrowings from te reo Māori. Te Reo, 49: 101-124.

Macalister, J. (2006). The Māori presence in the New Zealand English lexicon, 1850-2000: Evidence from a corpus-based study. English World-Wide, 27(1): $1-24$.

Macalister, J. (2001). Introducing a New Zealand newspaper corpus. New Zealand English Journal, 15: 35-41.

Macalister, J. (1999). Trends in New Zealand English: Some observations on the presence of Māori words in the lexicon. New Zealand English Journal, 13:38-49.

McCreanor, T. (1989). Talking about Race. In Yensen H., Hague K., \& McCreanor T. (Eds.), Honouring the Treaty. (pp. 90-112). Auckland: Penguin.

Ministry for Culture and Heritage. (2008). 100 Mãori words every New Zealander should know, Retrieved on 14 March 2009, from www.nzhistory.net.nz/culture/ maori-language-week/100-maori-words 
Moewaka Barnes, A., Gregory, A., McCreanor, T., Nairn, R., Pega, F., \& Rankine, J. (2005). Media and te Tiriti o Waitangi 2004. Auckland: Kupu Taea Media and te Tiriti Project.

NZPA. (2009, April 21). 70 jobs to go at Fairfax Media. Otago Daily Times. Retrieved on 30 April 2009, from www.odt.co.nz/news/national/52328/70-jobs-go-fairfaxmedia

Richmond, J.C. (1867). The New Zealand Parliamentary Debates, 862-863.

Spolsky, B. (2003). Reassessing Māori regeneration. Language in Society, 32(4): 553-578.

Te Puni Kōkiri. (2008). Te oranga o te reo Mäori 2006: The health of the Mäori language in 2006. Wellington: Te Puni Kōkiri.

Te Puni Kōkiri \& Te Taura Whiri i Te Reo Māori. (2003). Te rautaki reo Māori/The Māori language strategy. Wellington: Ministry of Māori Development.

Te Taura Whiri i te Reo Māori. (2008). What does the Māori Language Act 1987 do? Retrieved on 19 November 2008, from www.tetaurawhiri.govt.nz/english/ about_e/

Te Taura Whiri i te Reo Māori. (2008). Te Reo Māori.

Retrieved on 30 April 2009, from www.tetaurawhiri.govt.nz/english/issues_e/reo/ index.shtml

Te Taura Whiri i te Reo Māori. (2008). History. Retrieved on 9 June 2009, from www.tetaurawhiri.govt.nz/english/issues_e/hist/index.shtml

Trudgill, P., \& Hannah, J. (1994). International English: A guide to varieties of standard English. (3rd. ed.), London: Edward Arnold.

Waitangi Tribunal. (1989). Te reo Māori report: Wai 11 (2nd ed.). Wellington: GP Publications.

Westbrook, A. (2006). Te Reo Māori words in job advertisements: Lexemes of New Zealand English? Wellington Working Papers in Linguistics, 18: 31-48.

The authors are media, public health and film researchers, some of them experienced in newspaper journalism and video production. This article analyses a newspaper sample in the second of two pilot projects by the Kupu Taea: Media and te Tiriti Project. Other results from these projects were published by Kupu Taea in Media \& te Tiriti of Waitangi 2004 and Media \& te Tiriti of Waitangi 2007, available at www.trc.org.nz/resources/media.htm The authors would like to acknowledge funding of this project by the JR McKenzie Trust.

jrankine@actrix.co.nz 